\title{
Analisis Klasifikasi Data Tracer Study Dengan Support Vector Machine Dan Neural Network
}

\author{
${ }^{1}$ Drajat Indra Purnama, ${ }^{2}$ Rahmi Lathifah Islami, ${ }^{3}$ Lisna Sari, ${ }^{4}$ Pardomuan Robinson Sihombing \\ ${ }^{1}$ Badan Pusat Statistik Kabupaten Parigi Moutong, Sulawesi Tengah \\ ${ }^{2}$ Universitas Padjadjaran Bandung \\ ${ }^{3}$ Universitas Lampung \\ ${ }^{4}$ Badan Pusat Statistik \\ 1'drajatindrapurnama@bps.go.id, ${ }^{2}$ rahmilathifah.islami@gmail.com, ${ }^{3}$ lisnasari366@gmail.com, \\ ${ }^{4}$ robinson@bps.go.id
}

Diterima : 23 Februari 2021

Disetujui : 28 Maret 2021

\begin{abstract}
Perguruan tinggi secara rutin melakukan Tracer study setiap tahun yang berguna sebagai pemenuhan kebutuhan data akreditasi, perbaikan pembelajaran dan pengembangan kurikulum di perguruan tinggi agar bisa meningkatkan kualitas lulusan. Kualitas lulusan dapat dilihat dari kelancaran memperoleh pekerjaan setelah mahasiswa lulus dari perguruan tinggi. Semakin lancar lulusan memperoleh pekerjaan maka kualitas lulusan dianggap baik, sebaliknya semakin tidak lancar maka kualitas lulusan dianggap belum atau kurang baik. Penelitian ini bertujuan melakukan analisis klasifikasi waktu tunggu kerja untuk mengetahui tingkat kelancaran alumni dalam mendapatkan pekerjaan menggunakan metode klasifikasi Support Vector Machines (SVM) dan Backpropagation Neural Network (BPNN). Kedua metode klasifikasi baik BPNN dan SVM dengan fungsi Kernel Anova dapat menggambarkan klasifikasi data tracer study berdasarkan tingkat kelancaran alumni untuk mendapatkan pekerjaan (lancar dan tidak lancar) dengan tingkat akurasi yang hampir sama, yaitu sebesar $83,33 \%$ untuk tangkat akurasi BPNN dan 83,00\% untuk tingkat akutasi SVM. Diharapkan dengan mengetahui faktor yang dapat mengklasifikasikan tingkat kelancaran dalam mendapatkan pekerjaan, pihak universitas dapat memberikan kebijakan yang relevan sehingga kualitas lulusan akan semakin baik,
\end{abstract}

Keyword: klasifikasi, neural network, Support Vector Machine, tracer study

\section{PENDAHULUAN}

Perguruan tinggi sebagai jejang pendidikan yang mampu mempersiapkan sekaligus mencetak lulusan agar mampu bersaing untuk berhadapan dengan dunia kerja. Lulusan yang mampu bersaing di dunia kerja menjadi ukuran bagi perguruan tinggi sehingga mampu menghasilkan lulusan yang berkualitas. Pekerjaan yang diperoleh lulusan merupakan tolak ukur keberhasilan perguruan tinggi berhasil dalam bidang pendidikan. Selain itu lamanya mendapat pekerjaan menjadi bagian dari tolok ukur kualitas lulusan. Lulusan yang lancar dalam memperoleh pekerjaan menandakan kualitas lulusan yang baik. Perguruan tinggi mempunyai sebuah sistem dan cara tersendiri dalam membentuk lulusan yang berkualitas. Menurut Direktorat Jenderal Pembelajaran dan Kemahasiswaan [1], perguruan tinggi diharuskan untuk melaksanakan Tracer study dengan rutin setiap tahun untuk pemenuhan kebutuhan perbaikan pembelajaran, data akreditasi serta pengembangan kurikulum. Hal ini tidak dimaksudkan untuk membuat kurikulum yang seragam atau otonomi dari perguruan tinggi dikurangi, akan tetapi bahwa kompilasi data nasional yang diperoleh menjadi akurat karena dibutuhkan untuk pengambilan kebijakan yang berkaitan dengan pendidikan tinggi pada tingkat nasional melalui data Tracer study.

Terdapat beberapa faktor internal yang dapat mempengaruhi seorang lulusan perguruan tinggi dalam memperoleh pekerjaan setelah lulus. Menurut Kurniawati [2], lama lulusan dalam memperoleh pekerjaan dipengaruhi oleh Indeks Prestasi Komulatif (IPK) dan kemampuan soft skills. Faktor eksternal lain yang dapat berpengaruh adalah lama studi, pengalaman selama kuliah, pengetahuan, cara yang ditempuh dalam mendapatkan pekerjaan dan sebagainya. Informasi lulusan dari perguruan tinggi dapat digunakan untuk bahan pertimbangan untuk menyusun standar kompetensi. Tidak sedikit mahasiswa yang lulus tetapi harus menunggu dalam mendapatkan pekerjaan bahkan ada yang sampai bertahun-tahun, tetapi tidak jarang juga yang mendapat pekerjaan setelah lulus. Hal ini 
dapat berpengaruh terhadap penilaian untuk sebuah perguruan tinggi tentang bagaimana perguruan tinggi mampu membentuk lulusan yang berkualitas sehingga mudah dalam memperoleh pekerjaan. Selain itu terdapat faktor eksternal yang memungkinkan berpengaruh besar terhadap lama lulusan mendapat pekerjaan adalah berkurangnya ketersediaan lapangan pekerjaan yang tidak sebanding bila dibandingkan dengan bertambahnya jumlah alumni Perguruan Tinggi terhadap permintaan dunia kerja. Berdasarkan hal tersebut maka diperlukan pengklasifikasian waktu tunggu kerja untuk mengetahui tingkat kelancaran alumni dalam mendapatkan pekerjaan.

Menurut Han et al [3], klasifikasi merupakan sebuah teknik analisis data yang berfungsi untuk mencari sekumpulan pola, model ataupun fungsi yang mampu menggambarkan, membedakan dan mengelompokkan objek data ke dalam beberapa kelas tertentu. Terdapat 3 (tiga) tahapan dalam klasifikasi. Pertama, melakukan identifikasi dengan membentuk model dengan data training. Kedua, melakukan evaluasi model yang diperoleh pada tahap pertama. Yang terakhit atau ketiga, menerapkan model yang telah dievaluasi menggunakan data testing. Variabel dalam klasifikasi terdiri dari variabel prediktor dan variabel respon yang berupa variabel kategorik ordinal atau nominal. Variabel predictor merupakan faktor-faktor yang berpengaruh atau mampu menggambarkan variabel respon.

Metode data mining adalah salah satu metode yang digunakan dalam melakukan klasifikasi. Menurut Maimon dan Rokach [4], data mining dikelompokkan dalam dua kelompok besar verification dan discovery. Metode verification adalah metode yang umumnya merupakan teknik-teknik statistik, sebagia contohnya adalah goodness of fit, analisis variansi dan hypothesis testing. Sedangkan metode discovery dibedakan menjadi model deskriptif dan model prediktif. Model prediktif merupakan model yang melakukan prediksi terhadap data dengan hasil yang sudah diketahui pada data laim. Model ini diperoleh berdasarkan pada data historis lain dengan teknik regresi dan klasifikasi. Metode klasifikasi dapat digunakan antara lain bayesian networks, neural networks, Support Vector Machines, decision trees, dan instance based.

Berdasarkan pada penjelasan di atas, pada penelitian ini penulis tertarik melakukan analisis klasifikasi waktu tunggu kerja untuk mengetahui tingkat kelancaran alumni dalam mendapatkan pekerjaan dengan menggunakan metode klasifikasi Support Vector Machines (SVM) dan Backpropagation Neural Network (BPNN). Penelitian sebelumnya mengenai klasifikasi terhadap waktu tunggu kerja menggunakan SVM adalah penelitian yang dilakukan oleh Amrinda [5]. Dalam penelitian tersebut metode SVM memperoleh akurasi yang lebih baik daripada metode Naïve Bayes Classification. Sedangkan penelitian terhadap peramalan pekerjaan pertama alumni menggunakan BPNN adalah penelitian dari Affandi dkk [6]. Diharapkan penelitian ini mampu memperoleh tingkat akurasi yang baik dalam pengklasifikasian waktu tunggu kerja khususnya untuk alumni Universitas Lampung sesuai dengan metode yang digunakan dan dapat dijadikan sebagai acuan perguruan tinggi dalam persiapan alumni setelah lulus khususnya dalam mendapatkan pekerjaan.

\section{LANDASAN TEORI}

\section{A. Klasifikasi}

Klasifikasi merupakan bagian dalam machine learning dimana klasifikasi merupakan sebuah proses pembelajaran dari sebuah $f$ sebagai fungsi target yang mampu memetakan tiap himpunan atribut $x$ ke dalam salah satu label class dependen yang sudah didefinisikan sebelumnya [7]. Tahapan dalam klasifikasi antara lain adalah training dan testing. Proses training merupakan proses pembelajaran menggunakan data training. Proses testing merupakan proses melakukan pengujian terhadap model yang diperoleh pada proses training degan menggunakan data testing.

\section{B. Support Vector Machine (SVM)}

Support Vector Machine (SVM) merupakan suatu algoritma yang dapat bekerja menggunakan nonlinear mapping. Hal ini berfungsi untuk melakukan transformasi data training awal ke dimensi baru yang memiliki dimensi yang lebih tinggi. Konsep SVM secara sederhana dapat dijelaskan sebagai usaha memperoleh hyperplane terbaik untuk pemisah 2 (dua) buah kelas secara linear pada input space [8]. Gambar 1 menunjukkan beberapa pattern sebagai anggota dua buah kelas +1 dan 1. Pattern pada kelas -1 disimbolkan menggunakan warna mera dan pattern pada kelas +1 disimbolkan menggunakan warna kuning. 


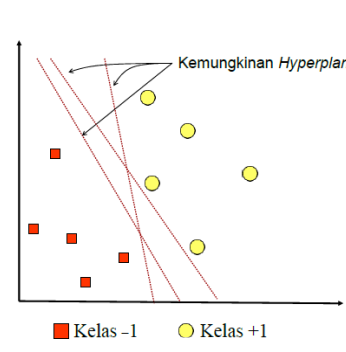

(a)

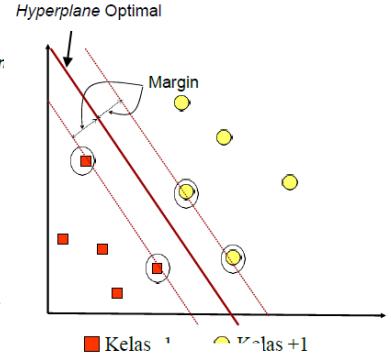

(b)
Gambar 1. (a). Kemungkinan Hyperplane Dalam Model Klasifikasi. (b). Hyperplane Optimal dengan Margin Optimal

Pada Gambar 1 (a) terdapat beberapa kemungkinan dalam mendapat hyperplane optimal untuk pemisah dua kelas secara linear pada input space. Hyperplane sebagai pemisah terbaik dari kedua kelas diperoleh dengan cara mengukur margin hyperplane serta mencari titik maksimal. Margin merupakan jarak hyperplane tersebut diukur dari pattern terdekat masingmasing kelas. Pattern terdekat ini merupakan support vector. Pada Gambar 1 (b), terdapat garis solid yang menunjukkan hyperplane terbaik. Hyperplane ini terletak tepat ditengah kedua kelas. Jarak garis solid dengan garis putus-putus adalah margin. Sedangkan titik kuning dan merah dialam lingkaran hitam merupakan support vector.

\section{Neural Network (NN)}

Jaringan syaraf tiruan atau Neural Network (NN) merupakan sistem prosesor parallel yang terhubung satu dengan yang lain dalam bentuk grafik. Jaringan syaraf tiruan dibuat sebagai suatu generalisasi model matematis dari pemahaman manusia dengan membuat struktur hierarkis dengan meniru fisiologi otak untuk memperoleh model baru pemecahan suatu masalah di dunia nyata.

Menurut Pebrianasari dkk [9], Neural Network (NN) terdiri atas 3 (tiga) lapisan. Pertama, input layer dengan unit-unit di dalam input layer yang disebut unit-unit input. Unitunit input ini menerima pola masukan data yang menggambarkan suatu permasalahan. Kedua, hidden layer dengan unit-unit di dalam hidden layer yang disebut unit-unit hidden. Output dari unit-unit hidden tidak bisa secara langsung diamati. Ketiga, output layer dengan unit-unit pada output layer disebut sebagai unit-unit output. Output dari layer merupakan solusi dari jaringan syaraf tiruan.

Salah satu metode Neural Network adalah Backpropagation Neural Network (BPNN). $B P P N$ merupakan metode sistematik untuk pelatihan multilayer jaringan syaraf tiruan. Metode ini mempunyai dasar matematis obyektif, kuat dan algoritma tersebut memperoleh nilai koefisien dan bentuk persamaan pada formula dengan jalan meminimalkan jumlah kuadrat galat error dengan model yang dikembangkan [10]. Jaringan syaraf BPNN juga terdiri dari 3 lapisan seperti pada NN [11] .

Proses BPNN diawali pada pembacaan data input, bobot awal, parameter training ( maksimum epoch, learning rate, target error), dan target output. Proses feedforward dimulai dengan pembacaan bobot awal, bias awal dan pembacaan nilai input kemudian dilanjutkan ke lapisan hidden hingga lapisan output. Jika nilai error lebih besar dari target error, maka proses feedforward dilanjutkan pada proses backpropagation yang berguna nilai error lebih kecil dengan cara memperbaiki nilai bobot dan bias dari setiap lapisan. Proses feedforward dan backpropagation berlangsung berulang hingga didapatkan tujuan training yaitu jumlah epoch (jumlah perulangan backpropagation dan proses feedforward) yang lebih besar atau sama dengan maksimum epoch, atau nilai target error lebih kecil atau sama dengan output [9].

\section{Evaluasi}

Tahapan penting dalam proses klasifikasi adalah melakukan evaluasi performa klasifikator. Salah satu cara dalam melakukan evaluasi performa klasifikator yaitu dengan confusion matrix. Confusion matrix adalah alat yang digunakan untuk menganalisa baik atau buruknya klasifikator mampu mengenali objek dalam kelas yang berbeda [3]. Misalkan jumlah kelas adalah $\mathrm{m}$, maka untuk $\mathrm{m} \geq 2$, ukuran confusion matrix adalah $m \times m$. Bentuk standar dari confusion matrix multi kelas dapat dilihat pada Tabel 1.

Tabel 1. Confussion Matrix

\begin{tabular}{|c|c|c|c|c|c|}
\hline \multirow{2}{*}{$\begin{array}{c}\text { Kelas } \\
\text { Target }\end{array}$} & \multicolumn{5}{|c|}{ Kelas Outpu } \\
\cline { 2 - 6 } & $\mathbf{1}$ & $\mathbf{2}$ & $\mathbf{3}$ & $\ldots$ & $\boldsymbol{J}$ \\
\hline 1 & $C_{11}$ & $C_{12}$ & $C_{13}$ & $\ldots$ & $C_{1 j}$ \\
\hline 2 & $C_{21}$ & $C_{22}$ & $C_{23}$ & $\ldots$ & $C_{2 j}$ \\
\hline 3 & $C_{31}$ & $C_{32}$ & $C_{33}$ & $\ldots$ & $C_{3 j}$ \\
\hline$\ldots$ & $\ldots$ & $\ldots$ & $\ldots$ & $\ldots$ & $\ldots$ \\
\hline$I$ & $C_{i 1}$ & $C_{i 2}$ & $C_{i 3}$ & $\ldots$ & $C_{i j}$ \\
\hline
\end{tabular}

Pada Tabel 1 terdapat $C_{i j}$ yang merupakan jumlah objek dalam kelas $i(i=1,2,3, \ldots)$ yang diklasifikasikan dalam kelas $j(j=1,2,3, \ldots)$. Diagonal utama confussion matrix menunjukkan 
sejumlah objek pada kelas $i$ yang dapat diklasifikasikan dengan benar oleh sistem [12]. Parameter penting dalam mengukur performa berdasarkan confusion matrix adalah akurasi, nilai error rate dan F-skor.

Akurasi merupakan perbandingan antara jumlah keseluruhan objek dengan jumlah diagonal utama confusion matrix. Pada jumlah kelas sebesar $m$ dengan $i, j=1,2, \ldots, m$ definisi akurasi tersebut mampu diformulasikan menggunakan persamaan (1). Nilai akurasi yang semakin mendekati 100 persen menunjukkan performa klasifikator semakin tinggi.

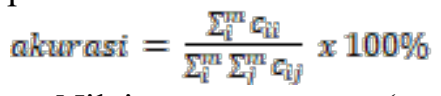

Nilai error rate (misclassification rate) dapat digunakan sebagai penentu performa dari suatu sistem klasifikasi. Nilai error rate semakin tinggi menunjukkan semakin buruk klasifikator. Sebaliknya, jika nilai error rate semakin rendah maka semakin baik klasifikator.

Error rate $=1-$ akurasi

Parameter terakhir yang digunakan untuk menentukan performa model klasifikasi yaitu Fskor. F-skor pada kelas $i$ melibakan nilai recall dan precision, dituliskan pada persamaan (3).

$$
F-\text { Skon }_{1}=2 \cdot \frac{\text { Precision }_{1} x \text { Recall }_{i}}{\text { Precision }_{i}+\text { Recall }}
$$

dengan Precision $_{\mathrm{i}}$ adalah perbandingan antara jumlah objek yang diklasifikasi dibandingkan dengan benar sebagai kelas $i$ oleh sistem terhadap jumlah objek yang diklasifikasikan sebagai kelas $i$. Sedangkan Recall $l_{i}$ merupakan perbandingan antara jumlah objek yang diklasifikasi dengan benar sebagai kelas $i$ oleh sistem terhadap jumlah objek kelas target $i$. Jika jumlah kelas $m$ maka rumus Precision $_{i}$ dan Recall ${ }_{i}$ dituliskan pada persamaan (4) dan (5).

$$
\begin{aligned}
& \text { Recall }_{i}=\frac{C_{i i}}{\sum_{i}^{m} C_{i i j}} \\
& \text { Precision }_{i}=\frac{C_{i i}}{\sum_{i i}^{m} C_{i i}}
\end{aligned}
$$

\section{E. Data dan Sumber Data}

Penelitian ini menggunakan data Tracer study Universitas Lampung (Unila) pada Tahun 2018 yang diperoleh dari UPT. Pengembangan Karir dan Kewirausahaan Universitas Lampung. Data yang digunakan adalah data sekunder hasil survei terhadap alumni yang lulus pada tahun 2016. Tekniknya adalah dengan wawancara langsung melalui telepon ataupun melalui media social. Jumlah data yang digunakan adalah 1500 data alumni dengan riwayat mencari pekerjaan. Untuk yang tidak pernah mencari pekerjaan sama sekali baik melanjutkan studi maupun berwirausaha tidak dimasukan dalam objek penelitian. Variabel penelitian terdiri dari variabel independen antara lain Program Studi (X1), Jenjang Pendidikan (X2), Indeks Prestasi Kumulatif (X3), Lama Studi (X4), Cara Mendapatkan Pekerjaan-Relasi (X5), Cara Mendapatkan Pekerjaan-Media Online (X6), Cara Mendapatkan Pekerjaan-Mandiri (X7), Penguasaan Pengetahuuan di Luar Program Studi Studi (X8) dan variabel dependennya adalah Waktu Tunggu Kerja (Y).

\section{HASIL DAN PEMBAHASAN}

\section{A. Statistik Deskriptif}

Tahapan awal penelitian ini adalah melakukan analisis statistik deskriptif guna melihat karakteristik data yang digunakan dalam penelitian. Karakteristik data yang akan dijelaskan diantaranya tingkat kelancaran alumni mendapatkan pekerjaan, program studi, jenjang pendidikan, IPK, lama studi, cara mencari pekerjaan, dan penguasaan di luar program studi.

Hasil analisis data Tracer study menunjukkan bahwa tingkat kelancaran alumni mendapatkan pekerjaan dengan lancar adalah sebesar 70,93 persen dan tingkat kelancaran alumni mendapatkan pekerjaan dengan tidak lancar sebesar 29,07 persen. Jika dilihat dari sisi program studi, program studi eksak memiliki persentase 43,93 persen dan program studi non eksak memiliki persentase sebesar 56,07 persen. Jika dilihat dari jenjang Pendidikan, S1 memiliki persentase 91,93 persen sedangkan D3 memiliki persentase sebesar 8,07 persen. Cara mencari pekerjaan dengan relasi memiliki persentase 57,80 persen sedangkan cara mencari pekerjaan bukan dengan relasi memiliki persentase 42,20 persen. Cara mencari pekerjaan dengan online memiliki persentase 49 persen sedangkan cara mencari bekerjaan bukan dengan online memiliki persentase 51 persentase. Cara mencari pekerjaan dengan mandiri memiliki persentase 51,33 persen sedangkan cara mencari pekerjaan bukan dengan mandiri memiliki persentasi 48,67 persen. Jika ditinjau dari IPK mahasiswa, IPK kurang dari 2,75 memiliki persentase 2,40 persen, IPK 2,76 - 3,5 memiliki persentase 57,73 persen dan IPK lebih dari 3,5 memiliki persentase sebesar 39,87 persen. Terakhir, dari sisi lama studi persentase tertinggi adalah lama studi 4 (empat) tahun yaitu 49 persen sedangkan lama studi 11 (sebelas) tahun memiliki persentase terkecil sebesar 0,20 persen. 


\section{B. Model Klasifikasi SVM}

Model klasifikasi pada penelitian ini dengan metode SVM menggunakan 4 (empat) kernel antara lain radial, linier, anova dan polynomial. Proses training dan testing serta validasi berada pada proses split data. Proses olah data menggunakan RapidMiner Studio Trial 9.2.001. Proses split data yang digunakan adalah split data 70 persen : 30 persen dan 80 persen : 20 persen. Model klasifikasi terbaik menggunakan metode SVM dengan nilai parameter optimal ditampilkan pada Tabel 2. Dapat dilihat Pada Tabel 2 bahwa model SVM terbaik merupakan model SVM menggunakan fungsi kernel anova dengan tingkat akurasi tertinggi sebesar 83 persen dan error terkecil yaitu 0,381 .

Tabel 2. Nilai Parameter Optimal pada Model Klasifikasi

\begin{tabular}{|l|c|c|c|c|c|}
\hline \multicolumn{1}{|c|}{$\begin{array}{c}\text { Fungsi } \\
\text { Kernel }\end{array}$} & Gamma & Cost & $\begin{array}{c}\text { Split } \\
\text { Data }\end{array}$ & $\begin{array}{c}\text { Tingkat } \\
\text { Akurasi }\end{array}$ & RMSE \\
\hline Linier & - & 0 & & $82,67 \%$ & 0,392 \\
\hline Radial & 0,1 & 0 & $80 \%:$ & $83,00 \%$ & 0,383 \\
\hline Polynomial & - & 1 & $20 \%$ & $82,67 \%$ & 0,386 \\
\hline Anova & 0,1 & 0 & & $83,00 \%$ & 0,381 \\
\hline
\end{tabular}

Model klasifikasi SVM menggunakan fungsi kernel anova berdasarkan nilai parameter optimal yang telah diperoleh dapat digunakan untuk menentukan hyperplane, sehingga dihasilkan nilai bobot $(w)$ dan nilai bias disajikan pada Tabel 3.

Tabel 3.Nilai Bobot (w) dan Bias pada Metode SVM

\begin{tabular}{|l|c|c|}
\hline \multicolumn{1}{|c|}{ Attribute Variable } & Bobot $(\boldsymbol{w})$ & Bias \\
\hline Program Studi & 0,034 & \\
\hline Jenjang Pendidikan & $-0,013$ & \\
\hline IPK & $-0,003$ & \\
\hline Lama Studi & $-0,039$ & \multirow{2}{*}{0,912} \\
\cline { 1 - 2 } $\begin{array}{l}\text { Cara Mencari Pekerjaan } \\
\text { Relasi }\end{array}$ & 0,299 & \\
\cline { 1 - 2 } $\begin{array}{l}\text { Cara Mencari Pekerjaan } \\
\text { Online }\end{array}$ & $-0,056$ & \\
\cline { 1 - 2 } $\begin{array}{l}\text { Cara Mencari Pekerjaan } \\
\text { Mandiri }\end{array}$ & 0,011 & \\
\cline { 1 - 2 } $\begin{array}{l}\text { Penguasaan Pengetahuan } \\
\text { di luar program studi }\end{array}$ & 0,078 & \\
\hline
\end{tabular}

Hasil proses klasifikasi berupa confusion matrix berisi jumlah observasi yang berhasil atau gagal dikelompokkan ke dalam kelasnya, dapat dilihat pada Tabel 4.
Tabel 4. Confusion Matrix pada Metode SVM Fungsi Kernel Anova

\begin{tabular}{|l|c|c|c|}
\hline \multirow{2}{*}{ Prediksi } & \multicolumn{2}{|c|}{ Aktual } & \multirow{2}{*}{\begin{tabular}{c} 
Class \\
\cline { 2 - 3 }
\end{tabular}} \\
\cline { 2 - 3 } Lancar & $\begin{array}{c}\text { Tidak } \\
\text { Lancar }\end{array}$ & Precision \\
\hline Lancar & 213 & 51 & $80,68 \%$ \\
\hline Tidak Lancar & 0 & 36 & $100,00 \%$ \\
\hline Class Recall & $100,00 \%$ & $41,38 \%$ & \\
\hline
\end{tabular}

Sedangkan ukuran ketepatan klasifikasi pada metode SVM menggunakan fungsi kernel anova dapat dilihat pada Tabel 5 .

Tabel 5. Ukuran Ketepatan Klasifikasi pada Metode SVM Fungsi Kernel Anova

\begin{tabular}{|l|c|}
\hline Ukuran Ketepatan Klasifikasi & Nilai \\
\hline Tingkat akurasi & $83,00 \%$ \\
\hline Precision & $100,00 \%$ \\
\hline Recall & $41,38 \%$ \\
\hline
\end{tabular}

Berdasarkan Tabel 4 dan Tabel 5 dapat ditunjukkan metode SVM menggunakan fungsi kernel anova memiliki akurasi sangat baik yakni sebesar 83,00 persen. Nilai precision dan recall berturut-turut memiliki sebesar 100,00 persen dan 41,38 persen. Hal ini berarti bahwa ketepatan klasifikasi tingkat kelancaran alumni Universitas Lampung untuk mendapatkan pekerjaan (lancar dan tidak lancar) akan tepat namun masih dapat terjadi kesalahan klasifikasi. Berdasarkan hal tersebut dapat disimpulkan bahwa metode SVM menggunakan fungsi kernel anova dapat memberikan tingkat performansi cukup baik sehingga model klasifikasinya dapat digunakan dengan cukup baik untuk memprediksi tingkat kelancaran alumni Universitas Lampung untuk mendapatkan pekerjaan (lancar dan tidak lancar).

\section{Model Klasifikasi BPNN}

Model klasifikasi pada penelitian ini menggunakan metode BPNN menggunakan proses split data dengan menentukan proporsi data yang akan dijadikan data training dan data testing. Proses split data yang digunakan yaitu split data 70 persen : 30 persen dan 80 persen : 20 persen. Parameter BPNN yang ditetapkan adalah nilai training cycle sebesar 200, momentum sebesar 0,9 dan error epsilon sebesar 1,0E-4. Parameter yang dijadikan parameter pembanding adalah learning rate yang ditetapkan sebesar 0,$1 ; 0,3 ; 0,5$ dan 0,6. Proses olah data menggunakan RapidMiner 
Studio Trial 9.2.001. Hasil uji coba menggunakan beberapa nilai learning rate yang telah ditetapkan nilainya yaitu 0,$1 ; 0,3 ; 0,5$ dan 0,6 ditampilkan pada Tabel 4.6.

Tabel 6. Confusion Matrix pada Metode BPNN

\begin{tabular}{|c|c|c|c|}
\hline \multirow[b]{2}{*}{ Prediksi } & \multicolumn{2}{|c|}{ Aktual } & \multirow{2}{*}{$\begin{array}{c}\text { Class } \\
\text { Precision }\end{array}$} \\
\hline & Lancar & $\begin{array}{c}\text { Tidak } \\
\text { Lancar }\end{array}$ & \\
\hline Lancar & 213 & 50 & $80,99 \%$ \\
\hline TidakLancar & 0 & 37 & $100,00 \%$ \\
\hline Class Recall & $100,00 \%$ & $42,53 \%$ & \\
\hline
\end{tabular}

Sedangkan ukuran ketepatan klasifikasi menggunakan Metode BPNN dapat dilihat pada Tabel 7.

Tabel 7. Ukuran Ketepatan Klasifikasi pada Metode BPNN

\begin{tabular}{|l|c|}
\hline Ukuran Ketepatan Klasifikasi & Nilai \\
\hline Tingkat akurasi & $83,33 \%$ \\
\hline Precision & $100,00 \%$ \\
\hline Recall & $42,53 \%$ \\
\hline
\end{tabular}

Berdasarkan pada Tabel 6 dan Tabel 7 maka dapat dilihat bahwa tingkat akurasi untuk metode BPNN dengan split data 80 persen : 20 persen dengan learning rate 0,05 cukup baik yaitu sebesar 83,33 persen. Nilai precision dan recall memiliki nilai cukup yaitu secara berurutan sebesar 100,00 persen dan 42,53 persen artinya ketepatan klasifikasi untuk tingkat kelancaran alumni Universitas Lampung untuk mendapatkan pekerjaan (lancar dan tidak lancar) akan tepat namun masih dapat terjadi kesalahan klasifikasi. Berdasarkan keterangan di atas, maka dapat disimpulkan bahwa metode BPNN dapat memberikan tingkat performansi cukup baik. Hal ini berarti bahwa model klasifikasi dapat dengan cukup baik memprediksi tingkat kelancaran alumni Universitas Lampung untuk mendapatkan pekerjaan (lancar dan tidak lancar).

\section{Perbandingan Ketepatan Klasifikasi BPNN dan SVM}

Berikut ditampilkan perbandingan ketepatan klasifikasi BPNN dan SVM yang dapat dilihat di Tabel 8. Berdasarkan Tabel 8 dapat ditunjukkan bahwa antara metode BPNN dan SVM memiliki hasil yang tidak berbeda secara signifikan sehingga kita bisa menggunakan kedua metode tersebut untuk pengklasifikasikan data Tracer Study.
Tabel 8. Perbandingan Ketepatan Klasifikasi pada Metode BPNN dan SVM

\begin{tabular}{|l|c|c|}
\hline $\begin{array}{c}\text { Ukuran Ketepatan } \\
\text { Klasifikasi }\end{array}$ & $\begin{array}{c}\text { Neural } \\
\text { Network }\end{array}$ & SVM \\
\hline Tingkat akurasi & $83,33 \%$ & $83,00 \%$ \\
\hline Precision & $100,00 \%$ & $100,00 \%$ \\
\hline Recall & $42,53 \%$ & $41,38 \%$ \\
\hline
\end{tabular}

\section{KESIMPULAN}

Berdasarkan hasil dan pembahasan mengenai analisis tingkat kelancaran alumni Universitas Lampung dalam mendapatkan pekerjaan dengan metode SVM dan BPNN dalam proses pengklasifikasian data tracer study berdasarkan tingkat kelancaran (lancar dan tidak lancar), maka dapat diperoleh kesimpulan sebagai berikut :

1. Metode BPNN dapat menggambarkan klasifikasi data tracer study berdasarkan tingkat kelancaran alumni Universitas Lampung untuk mendapatkan pekerjaan (lancar dan tidak lancar) dengan parameter learning rate sebesar 0,05. Model klasifikasi tersebut memiliki tingkat akurasi sebesar 83,33 persen.

2. Metode SVM dapat menggambarkan klasifikasi data tracer study berdasarkan tingkat kelancaran alumni Universitas Lampung untuk mendapatkan pekerjaan (lancar dan tidak lancar). Model klasifikasi terbaik pada penelitian ini adalah metode SVM menggunakan fungsi kernel anova dengan parameter gamma sebesar 0,1 dan parameter cost sebesar 0 . Model klasifikasi tersebut memiliki tingkat akurasi sebesar 83,00 persen.

3. Metode BPNN dan metode SVM menggunakan fungsi kernel anova dapat menggambarkan klasifikasi data tracer study berdasarkan tingkat kelancaran alumni Universitas Lampung untuk mendapatkan pekerjaan (lancar dan tidak lancar) dengan tingkat akurasi yang hampir sama yaitu sebesar 83,33 persen untuk metode BPNN dan 83,00 persen untuk metode SVM menggunakan fungsi kernel anova. Hal ini berarti bahwa model klasifikasi sangat baik dalam memprediksi tingkat kelancaran alumni Universitas Lampung untuk mendapatkan pekerjaan (lancar dan tidak lancar). 
DAFTAR PUSTAKA

[1] Ristekdikti, "Undang-undang Republik Indonesia Tahun Nomor 12 Tahun 2012 tentang Pendidikan Tinggi," Ristekdikti, Jakarta, 2016.

[2] P. Kurniawati, "Analisis Faktor-faktor yang Mempengaruhi Lama Mencari Kerja Lulusan S1 Fakultas Ekonomi Universitas Andalas Periode Wisuda Tahun $2013 \quad-2016, " \quad$ Universitas Andalas, Padang, 2017.

[3] J. Han, M. Kamber, and J. Pei, Data Mining: Concept and Techniques, Third Edition, Waltham: Morgan Kaufmann Publishers., 2012.

[4] M. K. Maimon and L. Rokach, Data Mining And Knowledge Discovery Handbook, Israel: Springer, 2010.

[5] G. D. Amrinda, "Analisis Klasifikasi Waktu Tunggu Kerja dengan Metode Support Vector Machine dan Naive Bayes Classification," Universitas Islam Indonesia, Yogyakarta, 2018.

[6] L. Affandi, M. E. Apriani, and A. H. Ulum, 2020. Peramalan Pekerjaan Pertama Pada Mahasiswa Menggunakan Metode Backpropagation, Seminar Informatika Aplikatif Polinema (SIAP) 2020.

[7] T. Furey, 2000. Support Vector Machine Classification dan Validation Of Cancer Tissue Samples Using Microarray Expression Data, Bioinformatics, 2000.

[8] V. N. Vapnik, The Nature of Statistical Learning Theory, New York: Springer, 1995.

[9] V. Pebrianasari, E. Mulyanto, and E. Dolphina, 2015. Analisis Pengenalan Motif Batik Pekalongan Menggunakan Algoritma Backpropagation, Techno.COM, Universitas Dian Nuswantoro Semarang, Vol. 14, No. 4, pp. 281-190.

[10] A. Nugroho, Bioinformatika dan Pattern Recognition, 2003.

[11] Wuryandari, M. Dessy, Afriant and Irawan, Perbandingan Metode Jaringan Syaraf Tiruan Backpropagation Dan Learning Vector Quantization Pada Pengenalan Wajah, Bandung.: Universitas Komputer Indonesia, 2012.

[12] C. Elkan, Evaluating Classifiers.,
California: University of California San

Diego, 2012. 